\title{
The Enforcement of MUI Fatwa Number 1 of 2003 concerning Copyright for Merchants Selling Pirated VCD and DVD in Manado City
}

\author{
Evra Willya ${ }^{1}$, Ahmad B. Bintang Maronrong ${ }^{2}$, Sabil Mokodenseho ${ }^{3}$ \\ ${ }^{1,2}$ Institut Agama Islam Negeri Manado - Indonesia, ${ }^{3}$ Universitas Islam Negeri Syarif \\ Hidayatullah Jakarta - Indonesia \\ 1evrawillya@iain-manado.ac.id, 2ahmadbintang035@gmail.com, \\ ${ }^{3}$ sabil.mokodenseho@gmail.com
}

\begin{abstract}
This article aims to determine the enforcement of the MUI Fatwa Number 1 of 2003 concerning Copyrights for Muslim merchants selling pirated VCDs and DVDs in Market 45, Manado City. A qualitative method with observation, interview, and documentation techniques was used to analyze the data. Of the six Muslim traders interviewed, the results showed that the MUI fatwa enforcement was ineffective due to the lack of socialization and evaluation of merchants. Also, the merchants did not stop selling pirated products because they lacked religious understanding and awareness and lived below the poverty line. At the same time, the authors' economic rights become a barrier to the public in accessing the product because it is valued beyond the ability of consumers. This study suggests that the MUI ought to pay attention to the economic balance between the authors' economic rights and the public, such as merchants.
\end{abstract}

Keywords: $\quad$ MUI fatwa; IPR; Muslim merchants; pirated products; VCDs and DVDs

[]

Tulisan ini dilakukan untuk melihat secara langsung pengimplementasian Fatwa MUI No.1 Tahun 2003 tentang Hak Cipta terhadap pedagang Muslim penjual VCD dan DVD bajakan di Pasar 45, Kota Manado. Metode kualitatif dengan teknik observasi, wawancara, dan dokumentasi, digunakan untuk menganalisis data. Dari enam pedagang Muslim yang diwawancarai, hasil penelitian menunjukkan bahwa pengimplementasian fatwa MUI tidak berjalan efektif karena kurangnya sosialisasi dan evaluasi terhadap para pedagang. Selain itu, pedagang tidak berhenti menjual produk bajakan karena minimnya pemahaman agama dan kesadaran para pedagang, serta rata-rata pedagang masih hidup di bawah garis kemiskinan. Pada saat yang sama, hak ekonomi yang diberikan kepada pemegang hak cipta menjadi penghalang bagi hak publikuntuk mengakses suatu produkyang dihasilkan karena dihargai di luar kemampuan konsumen. Penelitian ini menyarankan MUI memerhatikan keseimbangan ekonomi antara hak ekonomi pemegang hak cipta dan hak publik termasuk pedagang.

Kata Kunci: fatwa MUI; HAKI; pedagang muslim; produk bajakan; VCD dan DVD. 
Evra Willya, Ahmad B. Bintang Maronrong, Sabil Mokodenseho

\section{Introduction}

Rights are everything someone needs to own before birth, while freedom is the right of every individual to do something. ${ }^{1}$ Furthermore, humans are given the freedom to own property to meet their daily needs. ${ }^{2}$ This means that property ownership and control are an instinct of everyone. Therefore, natural rights such as Intellectual Property Rights (IPR) ought to be protected. ${ }^{3}$ The IPR is originated based on the intellectual work of a person ${ }^{4}$ in the fields of science, technology, ${ }^{5}$ arts, and literature. 6

According to Baklanova, Petrova, and Koval, the tightening of IPR in the globalization era becomes essential and exciting because its role determines the rate of national development of a country. ${ }^{7}$ This is in line with the statement of Woo, Jang, and Kim that the tightening of IPR affects the market expansion. However, in some developed and developing countries, IPR has volatile effects in different industries when overprotected. For example, industries in the chemical sector tend to benefit most from strengthened IPR, while complex industries such as those in the electronics and machinery sectors are negatively affected. ${ }^{8}$

\footnotetext{
1 Gehan Gunatilleke, 'Justifying Limitations on the Freedom of Expression', Human Rights Review 22, no. 1 (1 November 2020): 91-108, https://doi.org/10.1007/S12142-020-00608-8.

2 Steven A. Brieger et al., 'Prosociality in Business: A Human Empowerment Framework', Journal of Business Ethics 159, no. 2 (5 November 2019): 361-80, https://doi.org/10.1007/S10551-018-4045-5.

${ }^{3}$ Meirison Meirison and Zerly Nazar, 'Intellectual Property Rights and Monopoly in the Perspective of Islamic Jurisprudence', Al-Ahkam 31, no. 1 (29 April 2021): 49-68, https://doi.org/10.21580/AHKAM. 2021.31.1.6656.

4 Kamilia Loukil, Intellectual Property Rights, Human Capital and Innovation in Emerging and Developing Countries', Journal of Social Economics Research 7, no. 1 (2020): 35-41, https://doi.org/ 10.18488/journal.35.2020.71.35.41.

5 Zachary Cohle, 'Global Innovative R\&D Offshoring with Heterogeneous Labor: The Role of IPRProtection on Technology Transfer and the Brain Drain Effect', Southern Economic Journal 86, no. 2 (October 2019): 691-725, https://doi.org/10.1002/soej.12397.

${ }^{6}$ John Feather, 'Copyright and the Creation of Literary Property', in A Companion to the History of the Book, ed. Simon Eliot and Jonathan Rose (John Wiley \& Sons, Ltd, 2019), 743-57, https://doi.org/10. 1002/9781119018193.CH49.

7 Olena Baklanova, Mariana Petrova, and Viktor Koval, 'Institutional Transmission in Economic Development', Ikonomicheski Izsledvania 29, no.1 (2020): 68-91, https://ideas.repec.org/a/bas/econst/ y2020i1p68-91.html.

${ }^{8}$ Seokkyun Woo,Pilseong Jang, and Yeonbae Kim, 'Effects of Intellectual Property Rights and Patented Knowledge in Innovation and Industry Value Added: A Multinational Empirical Analysis of Different Industries', Technovation 43-44 (1 September 2015): 49-63, https://doi.org/10.1016/J. TECHNOVATION.2015.03.003.
} 
The statements of Woo, Jang, and Kim illustrate that the tightening of IPR has not been maximized. Several copyright infringement cases marked the statement in developing and developed countries, such as Indonesia and China. ${ }^{9}$ However, this makes it difficult for the work's creator because his creativity, which deserves to be appreciated, seeks profit from various irresponsible parties..

According to the Law of the Republic of Indonesia Number 19 of 2002 concerning Copyright, copyright is the exclusive right of the creator or copyright holder to publish or reproduce his work, which arises automatically after the work is created without reducing restrictions according to the applicable laws and regulations. ${ }^{10}$ Meanwhile, in Law Number 28 of 2014 concerning Copyright, these rights are intellectual property granted by the Indonesian government to creators in science, literature, and art and have a strategic role in supporting national development.11 For example, computer software is protected by copyright granted by the government. Therefore, protection is based on a declarative principle attached to the creator as soon as the idea is realized in the form of a work.

According to Olivia, copyright protection in some countries is different. The United States protects intellectual works with copyrights and patents. This type of patent in this country is quite popular compared to Indonesia. At the same time, the most appropriate intellectual protection for computer software is through copyright. Patent protection for computer software hinders science and innovation because it prevents others from using specific mathematical algorithms. Copyright protection helps software developers to create their code by applying the same methods that already exist.12 Therefore, the protection of

\footnotetext{
${ }^{9}$ James A Brander, Victor Cui, and Ilan Vertinsky, 'China and Intellectual Property Rights: A Challenge to the Rule of Law', Journal of International Business Studies 48, no. 7 (September 2017): 908-21, https://doi.org/10.1057/s41267-017-0087-7.

10 Indonesian Law Number 19 of 2002 concerning Copyright, Chapter II Scope of Copyright, Part One Function and Nature of Copyright, Article 2 Point 1

${ }^{11}$ Nina Nurani and Hafied Noor Bagja, "The Effectiveness of Act Number 19 Year 2002 Jo. Act Number 28 Year 2014 Concerning with Copyright as a Protection of Craft Creative Industry to Increase the Acceleration of Creative Economic Growth of Indonesia', Global Business and Management Research: An International Journal 11, no. 1 (2019): 249-61.

12 Denindah Olivia, 'Intellectual Property Regimes to Protect Computer Software: Indonesia and the United States', Legal Brief 10, no. 1 (November 2020): 8-16, http://legal.isha.or.id/index.php/legal/ article/view/28.
} 
computer programs in Indonesia encourages creativity, competition, and technological progress.

Indonesia has a diversity of ethnicities, cultures, and religions, which are potentials for the nation to be protected. ${ }^{13}$ In addition to many developments and developments in trade, industry, and active investment, which also requires copyright protection of intellectual property. ${ }^{14}$ The creators and rights owners ${ }^{15}$ need protection while taking into account the public interest.

However, in Indonesia, copyright infringement is included in the high category. Ari Juliano Gema, Deputy for Facilitation and Regulation of Intellectual Property Rights at the Creative Economy Agency, said that Indonesia lost trillions of rupiah due to high piracy rates. The leading cause is the lack of public awareness in appreciating the intellectual works of others. Gema based it on a study conducted by the Faculty of Economics and Business at the University of Indonesia on film piracy. The results show that losses in only four cities, namely Bogor, Jakarta, Deli Serdang, and Tangerang, reached 1.4 trillion rupiah due to illegal downloading and DVD piracy. ${ }^{16}$ While in the music sector, in 2017, the Indonesian Recording Industry Association recorded a loss of 8.4 trillion rupiahs. Furthermore, the Indonesian Society Against Piracy data shows that the country has suffered 12 trillion rupiahs in software piracy. ${ }^{17}$

The data above shows that there are still many copyright violations in Indonesia, a productive country in making laws that protect IPR. These laws

13 Lorraine V. Aragon, "The Problems of Owning Culture: Global Intellectual Property Law and "traditional" Community Arts in Indonesia', Asian Ethnicity 13, no. 4 (September 2012): 399-417, https://doi.org/10.1080/14631369.2012.710077; Ismail Suardi Wekke and Sabil Mokodenseho, 'Religious Teaching and Learning in Minority Muslim of Manado Indonesia', in 2nd International Conference on Education, Science, and Technology (ICEST 2017), ed. Gufran Darma Dirawan (Atlantis Press, 2017), 187-89, https://doi.org/10.2991/icest-17.2017.62.

${ }^{14}$ Christianity Winner Baene, 'Analysis of the Effect of Industrial Sector Exports, Foreign Investment Industrial Sector and Inflation on Indonesia Gross Domestic Product in 1983-2017', International Journal Public Budgeting, Accounting and Finance 4, no. 1 (February 2021): 1-10.

15 Ifeoluwa A Olubiyi, Aishatu E Adaji, and Ayokunle F Adetula, Increasing the Commercial Value of Image Rights in Nigeria: Legal Possibilities', Journal of Intellectual Property Law \& Practice 15, no. 3 (March 2020): 193-97, https://doi.org/10.1093/jiplp/jpz177.

16 Bayu Anggoro, 'Pembajakan Hak Cipta di Indonesia Masih Tinggi', Media Indonesia, September 2019, https://mediaindonesia.com/nusantara/258462/pembajakan-hak-cipta-di-indonesia-masihtinggi.

17 Rio Tuasikal, 'Rugi 20 Triliun, Pemerintah Perangi Produk Bajakan', September 2019, https://www.voaindonesia.com/a/rugi-20-triliun-pemerintah-perangi-produk-bajakan/5077678. html. 
include Law Number 6 of 1982 concerning Copyright, Law Number 19 of 2002 concerning Copyright, Law Number 14 of 2001 concerning Patents, Law Number 15 of 2001 concerning Marks, Law Number 29 of 2000 concerning Protection of Plant Varieties, Law Number 30 of 2000 concerning Trade Secrets, Law Number 31 of 2000 concerning Industrial Design, and Law Number 32 of 2000 concerning Layout of Integrated Circuits.

In addition, the Council of Indonesian 'Ulama (MUI) has also issued a fatwa in protecting IPR. The MUI is an institution made up of various Muslim clerics and scholars, funded by the government and tasked with issuing collective fatwas. ${ }^{18}$ This institution is similar to Islamic institutions in other countries that function as intermediaries between the government and the ummah. Since 1975, the MUI fatwa has answered various problems, ranging from faith, worship, ${ }^{19}$ sharia banking, ${ }^{20}$ halal certification, halal tourism, ${ }^{21}$ and other industries. ${ }^{22}$

The MUI at least issued two fatwas related to IPR, namely Fatwa Number 1 of 2003 regarding Copyright and Fatwa Number 1/MUNAS VII/MUI/15/2005 concerning Protection of Intellectual Property Rights. It is not the number of fatwas, but the most important thing is how the rules are enforced to the public in terms of socialization and evaluation. It makes the effectiveness of these rules known. The results show that MUI fatwas contributed actively to the transformation of Islamic law during the period 1975 to 2011. Over the 36 years,

18 'Indonesian Presidential Regulation Number 151 of 2014 Concerning Funding Assistance for the Activities of the Indonesian Ulema Council', Pub. L. No. 151 of 2014 (n.d.), http://www.bphn.go.id/data/ documents/14pr151.pdf.

19 Syafiq Hasyim, 'Fatwas and Democracy: Majelis Ulama Indonesia (MUI, Indonesian Ulema Council) and Rising Conservatism in Indonesian Islam', TRaNS: Trans-Regional and-National Studies of Southeast Asia 8, no. 1 (May 2020): 21-35, https://doi.org/10.1017/trn.2019.13.

20 Nurmusyahidah Nurmusyahidah, Arfin Hamid, and Andi Tenri Famauri, 'Problematic Financing Fine in Indonesian Ulema Council Perspective', International Journal of Multicultural and Multireligious Understanding 6, no. 5 (October 2019): 241, https://doi.org/10.18415/ijmmu.v6i5.1075.; Ma'ruf Amin, 'Fatwa and The Development of Islamic Financial Industry: A Lesson From Indonesia', Al-Iqtishad:Journal of Islamic Economics 9, no. 2 (May 2017): 331-50, https://doi.org/10.15408/aiq.v9i2.5353.

21 Suharko Suharko et al., 'Institutional Conformance of Halal Certifi Cation Organisation in Halal Tourism Industry: The Cases of Indonesia and Thailand', Tourism: An International Interdisciplinary Journal66, no. 3 (September 2018): 334-48.; Asad Mohsin, Noriah Ramli, and Bader AbdulazizAlkhulayfi, 'Halal Tourism: Emerging Opportunities', Tourism Management Perspectives (Elsevier, July 2016), https://doi.org/10.1016/j.tmp.2015.12.010.

22 Neng Yani Nurhayani and Sarip Muslim, 'Analysis of the Concept of Independence and Professionalism of Indonesian Ulema Council towards Halal Guarantee Certification on Processed Food Industry in West Java', International Journal of Nusantara Islam 7, no. 1 (March 2019): 49-61, https://doi.org/10.15575/ijni.v7i1.4370. 
MUI has issued 137 fatwas and 50 decisions for Muslims and the Indonesian government. According to Jamaa, the MUI fatwa is one element that contributes to the development of contemporary Islamic law in Muslim countries. ${ }^{23}$ However, there has been no comprehensive discussion of the MUI Fatwa Number 1 of 2003 concerning Copyright.

Therefore, further studies are needed to fill the void in the investigation because previous data shows that the MUI fatwa has not been influential. This study aims to determine the application of MUI Fatwa No. 1 of 2003 concerning Copyright by taking the case of Muslim traders who sell pirated VCDs and DVDs in Pasar 45, Manado city.

This study used a descriptive qualitative approach and aimed to produce descriptive data in the form of words and behavior from merchants and MUI fatwas. At the same time, the descriptive approach helped to describe the facts, properties, and relationships between the phenomena studied. A qualitative method was used to match empirical realities with relevant theories. This method is often called naturalistic because it is carried out in natural conditions. ${ }^{24}$ The aim was to comprehensively understand the phenomena experienced by the study subjects, such as behavior, motivation, actions, and others.

Data were collected by using the following methods: (1) Observations by going directly or paying attention to the object by using all the senses; ${ }^{25}$ (2) The use of unstructured interviews with Muslim merchants selling pirated VCDs and DVDs at Market 45, Manado city. Also, the use of the MUI to obtain relevant information that regards the enforcement of MUI Fatwa Number 1 of 2003 on Copyright, with several questions including (a) How is the enforcement of MUI Fatwa Number 1 of 2003 concerning Copyrights on Muslim merchants that sell pirated VCDs and DVDs at Market 45, Manado city?; (b) What is the reason why Muslim merchants practice selling pirated VCDs and DVDs to customers?; (c) Regarding the prohibition in selling pirated VCDs and DVDs products, is it following the objectives of the MUI Fatwa Number 1 of 2003 concerning

${ }^{23}$ La Jamaa, 'Fatwas of the Indonesian Council of Ulama and Its Contributions to the Development of Contemporary Islamic Law in Indonesia', IJIMS: Indonesian Journal of Islam and Muslim Societies 8, no. 1 (2018):29-56, https://doi.org/10.18326/ijims.v8i1.29-56.

24 Sugiono, Metode Penelitian Pendidikan: Pendekatan Kuantitatif, Kualitatif, dan R \& D (Bandung: Alfabeta, 2008), 8.

25 Suharsimi Arikunto, Prosedur Penelitian: Suatu Pendekatan Praktik (Jakarta: Rineka Cipta, 2013), 145. 
Copyright?; (3) The use of documentation to obtain supporting data from journal articles, books, MUI fatwas, and various relevant previous studies. The data of observation, interviews, and documentation were used to obtain a comprehensive data source. The population in this study was Muslim traders. The MUI with the targets to be interviewed were six people who traded at Pasar 45 Manado City and the Chairperson of the MUI of North Sulawesi.

The primary data sources were interviews given to the Muslim merchants that sell pirated VCDs and DVDs in Market 45, Manado City, and the MUI in the relevant regions. Generally, the existence and responses related to the MUI Fatwa Number 1 of 2003 concerning Copyright, factors supporting and hindering the sales process, and the profits from selling helped to answer the question related to the merchant's background for selling pirated products. Meanwhile, for MUI, the question is about the socialization and evaluation steps that they carried out after the fatwa was issued. Moreover, if needed, some questions are developed for the two objects. The secondary data sources are taken from journal articles, books, and others.

Qualitative methods are used because this research departs from assumptions, realities, or unique and complex social phenomena. There is a certain regularity or pattern, but it is full of variety and diversity. ${ }^{26}$ The steps taken are

1. Data collection through interview techniques helps obtain information related to the implementation of the MUI Fatwa Number 1 of 2003 concerning Copyright which is abstracted from primary data sources such as Muslim traders who sell pirated VCDs and DVDs in Pasar 45, Manado City, and MUI through conversations or questions and answers, as well as reviewing relevant theories;

2. All data collected through observation, interviews, and documentation are identified to facilitate the analysis process;

3. The last stage is to describe and analyze the data and relevant theories and present them in written form.

\section{Pirated VCD and DVD Selling Practices}

Currently, poverty is a scourge in Indonesian society, and this was indicated by the Central Statistics Agency (BPS) data that the number of poor people in

${ }^{26}$ Burhan Bungin, Analisa Data Penelitian Kualitatif(Jakarta: PT. Raja Grafindo Persada, 2003), 53. 
March 2020 reached $9.78 \%$ or 26.42 million. ${ }^{27}$ In September 2020, this number continued to increase and reached $10.19 \%$, or 27.55 million. The result showed that poor people in the urban area increased by 876.5 thousand in September 2020 compared to March 2020. It means the poverty rate increases from 11.16 million to 12.04 million. Meanwhile, the number of poor people in rural areas increased by 249.1 thousand, which means it increased from 15.26 million in March 2020 to 15.51 million in September 2020.28

Indonesia is one of the countries with the fourth largest population after China, India, and the United States. ${ }^{29}$ According to the population census results in September 2020, the total population of Indonesia was 270.20 million. ${ }^{30}$ However, people find it difficult to get a job when the large population is not balanced with adequate employment opportunities. According to Didik Junaidi Rachbini, a senior economist at the Institute for Development of Economics and Finance (INDEF), the open unemployment rate in 2021 will increase by $7.8 \%$ or 10.4 million people while the poverty rate is projected to reach $10.5 \%{ }^{31}$

The above data showed that many Indonesians are living below the poverty line and lack jobs. It brings about the emergence of new problems related to work because the lack of jobs and economic reasons do not allow people to obtain rupiah. The merchants of pirated VCDs and DVDs felt this experience. Therefore, they decided to carry out the illegal acts in various places in Indonesia, ${ }^{32}$ including Market 45, Manado City, North Sulawesi.

27 Badan Pusat Statistik, 'Persentase Penduduk Miskin Maret 2020 Naik Menjadi 9,78 Persen', July 2020, https://www.bps.go.id/pressrelease/2020/07/15/1744/persentase-penduduk-miskin-maret2020-naik-menjadi-9-78-persen.html.

28 Badan Pusat Statistik, 'Persentase Penduduk Miskin September 2020 Naik Menjadi 10,19 Persen', February 2021, https://www.bps.go.id/pressrelease/2021/02/15/1851/persentase-pendudukmiskin-september-2020-naik-menjadi-10-19-persen.html.

29 Dwi Hadya Jayani, 'Jumlah Penduduk Indonesia 269 Juta Jiwa, Terbesar Keempat di Dunia', 2019, https://databoks.katadata.co.id/datapublish/2019/04/29/jumlah-penduduk-indonesia-269-juta-jiwa -terbesar-keempat-dunia.

30 Badan Pusat Statistik Republik Indonesia, Potret Sensus Penduduk 2020 Menuju Satu Data Kependudukan Indonesia, ed. Direktorat Statistik Kependudukan dan Ketenagakerjaan (Jakarta: BPS RI, 2021).

31 Jaffry Prabu Prakoso, 'Pengangguran 2021 Diproyeksi Naik 2 Kali Lipat, Kemiskinan Bisa Double Digit', January 2021, https://ekonomi.bisnis.com/read/20210107/9/1339880/pengangguran-2021diproyeksi-naik-2-kali-lipat-kemiskinan-bisa-double-digit\#: :text=Pengangguran 2021 Diproyeksi Naik 2 Kali Lipat\%252C Kemiskinan Bisa Double Digit,-Ekonom Senior Institute\&text=Sekitar 2\%252.

32 Winsherly Tan, Elza Syarief, and Rina Shahriyani Shahrullah, 'Combatting Pirated VCDs/DVDs in Batam City, Indonesia: "Facts and Expectations'”, East European Business Law 24, no. 1 (2016): 1-10.; 
Although some laws and regulations prohibit the selling and buying of pirated products, some merchants do not hesitate to sell these products under various excuses they convey. Economic factors are the leading cause of this phenomenon. Irvan said that apart from being a motorcycle taxi driver, he also sold pirated VCDs and DVDs. The reason is that the profits obtained from selling these products can meet the needs of his family's life. ${ }^{33}$ Furthermore, Jhoni, a trader, said he had been selling VCDs and DVDs, both original and pirated, for five years. Even though the merchant knew that one of the sold products was pirated, ${ }^{34}$ he still sold it

In terms of profits from selling VCDs and DVDs, according to Sumiati Alatada, who has been selling pirated VCDs and DVDs for five years, pirated products are more profitable than the original ones. The traders also said that the profits reached Rp. 2,000,000/month if the market is full of buyers. She explained that buyers tend to look for pirated ones; besides being cheap, the quality is not inferior to the original..$^{35}$ Traders only take a small part in pirated products such as VCDs and DVDs as they are not responsible for reproducing such works. In addition, they only buy products from large dealers, which can be duplicated and then resold in the market. ${ }^{36}$

Some traders stated that all their activities stopped when the police came to conduct raids. According to Gobel, who has ten years of experience selling original and pirated VCDs and DVDs at Pasar 45 Manado City, the police always come to conduct raids. The police not only arrested him but also confiscated the remaining pirated VCDs and DVDs. ${ }^{37}$ The same thing happened to Iswan, who is also a trader

Denni Arli and Fandy Tjiptono, 'Consumer Digital Piracy Behaviour among Youths: Insights from Indonesia', Asia Pacific Journal of Marketing and Logistics 28, no. 5 (November 2016): 898-922, https://doi.org/10.1108/APJML-11-2015-0163.

33 Irvan (Pirated VCD and DVD Traders in 45 Markets, Manado City), interview with the author, Manado City, Indonesia, March 2021.

34 Jhoni (Pirated VCD and DVD Traders in 45 Markets, Manado City), interview with the author, Manado City, Indonesia, March 2021.

35 Sumiati Alatada (Pirated VCD and DVD Traders in 45 Markets, Manado City), interview with the author, Manado City, Indonesia, March 2021.

36 Nandito (Pirated VCD and DVD Traders in 45 Markets, Manado City), interview with the author, Manado City, Indonesia, March 2021.

37 Gobel (Pirated VCD and DVD Traders in 45 Markets, Manado City), interview with the author, Manado City, Indonesia, March 2021. 
of these pirated products. ${ }^{38}$ However, once again, due to economic factors, they continued to sell pirated VCDs and DVDs the next day.

The sustainability of the sale of pirated products occurs because the traders ignore the MUI fatwa. This factor makes the fatwa ineffective. This condition can be seen from the number of traders who sell pirated VCDs and DVDs who have never heard of the fatwa. Irvan, for example, said that in his ten years of trading, he had never heard of the fatwa. A little different from Sumiati, who claimed to have heard of the fatwa prohibiting the sale of pirated VCDs and DVDs. However, she did not hear it from the MUI. He said he heard it from a friend. ${ }^{39}$ This phenomenon proves that there is no socialization from MUI to traders.

Thus, based on the data and information above, the sales of pirated VCDs and DVDs at Pasar 45 Manado City that traders have carried out are due to three main reasons. First, the economic factor. Second, their ignorance of the prohibition of selling pirated goods. Third, their ignorance is caused by the absence of socialization from the MUI.

\section{Socialization and Evaluation of MUI Fatwa Number 1 of 2003 concerning Copyright}

The Muslim community needs the existence of MUI. Because it is an institution consisting of various Islamic organizations, scholars, legal experts, and the Indonesian government, this council assumes the responsibility of being a "mouthpiece" between the government and the people and vice versa and issues joint fatwas. It is to gather Indonesian scholars and find solutions to various problems in this nation.

K.H. Abdul Wahab Abdul Gafur, General Chair of North Sulawesi, said that MUI is an institution that directs and fosters Muslims in instilling the Islamic faith and enforcing sharia law to create a quality society (khayr ummah) in various aspects of life. Regarding the issue of socialization, he said that the fatwa needed to be disseminated. Although MUI does not touch the traders, there have been meetings

38 Iswan (Pirated VCD and DVD Traders in 45 Markets, Manado City), interview with the author, Manado City, Indonesia, March 2021.

${ }^{39}$ Alatada (Pirated VCD and DVD Traders in 45 Markets, Manado City), interview with the author, Manado City, Indonesia, March 2021. 
with the community and other mass organizations, both at the North Sulawesi office and elsewhere. 40

\section{Effectiveness of MUI Fatwa Number 1 of 2003 concerning Copyright for Merchants Selling Pirated VCDs and DVDs}

In Islam, copyright is seen as a property right that ought to receive legal protection. This religion prohibits theft such as the practice of piracy and copying of works that often occurs in Indonesia. According to Islamic law, this act is a criminal offense. Buying and selling pirated products is dangerous (ḍārār) because it harms others and does not obey the law. Although this helps the middle and lower class of the economy in the economic field, its dangers are both material and moral. ${ }^{41}$ There are several forms of loss, including ${ }^{42}$

1. The pirates do not appreciate the efforts of the author to produce his work which has taken time, energy, and funds;

2. The pirates do not recognize the author's services for the advancement of science, literature, and art;

3. The pirates do not recognize people or companies' services or publishers who provide capital to broadcast, print, and reproduce copyrighted works.

In addition, the company or publisher has to pay some taxes and author royalties. ${ }^{43}$ Meanwhile, the hijackers not only commit piracy but also do not pay royalties and taxes.

The practice of piracy not only harms the owner of the work but also harms the state. In the context of Islam, Assyaukanie stated that all efforts that can harm others are haram (forbidden). Therefore, copyright piracy is prohibited because it has illegally taken over someone else's property. This act is tantamount to stealing. It is illegal to reproduce or sell the copyright to acquire property without the author's permission. The prohibition occurs because a copyrighted work is

\footnotetext{
40 KH. Abdul Wahab Abdul Gafur (Chairman of the MUI of North Sulawesi province), interview with the author, North Sulawesi, Indonesia, April 2021.

41 Martin Eisend, 'Morality Effects and Consumer Responses to Counterfeit and Pirated Products: A Meta-Analysis', Journal of Business Ethics 154, no. 2 (January 2019): 301-23, https://doi.org/10.1007/ s10551-016-3406-1.

42 Marulam Hutauruk, Peraturan Hak Cipta Nasional, 1sted. (Jakarta: Erlangga, 1982), 108.

43 Robert M. Hurt and Robert M. Schuchman, 'The Economic Rationale of Copyright', The American Economic Review 56, no. 1/2 (1966): 421-32, https://www.jstor.org/stable/1821305.
} 
something that results from intellectual ability. It is also the result of a thought that has economic value. ${ }^{4}$

Eating other people's property in the wrong way is unlawful. Ahmād calls this practice eating in a vanity way (al-akl bi al-bātiil). ${ }^{45}$ Allah affirms this vanity act in Surah al-Nisa Verse 29. The Prophet also emphasizes the prohibition of cheating. Copyright protection should thus be reaffirmed. Through its fatwa Number 1 of 2003 and the Copyright Law, MUI needs to be re-expressed to explain the protection of works and copyrights.

The MUI fatwa Number 1 of 2003 concerning Copyright has met the criteria that ought to have been met. Therefore, the council refers to copyright protection to be good because it contains several reasons for the issuance of the law and why piracy needs to be prohibited. The fatwa does not include prohibitions for traders but, in general, for any acts of piracy. The reason is that selling pirated products is a form of copyright infringement. Article 72 of Law Number 19 of 2002 explains that copyright infringement as a legal offense is divided into three parts: (1) intentionally and without the right to publish, reproduce a work, or give permission. Such violation violates the prohibition to publish, reproduce or give permission for this work because it is contrary to government policy in the fields of defense and state security, decency, and public order. (2) Deliberately exhibiting, distributing, and selling to the public works or products resulting from copyright infringement. These violations include the sale of pirated books and VCDs. (3) Intentionally and without rights to reproduce the commercial use of the computer program.

Based on the interviews, this study found that the MUI Fatwa Number 1 of 2003 concerning Copyright has not been appropriately implemented. This finding is shown by the large number of traders who continue to sell pirated VCDs and DVDs. The data is alarming because the products sold are dominated by pirated products rather than genuine products.

\section{Factors Influencing Muslim Merchants to Sell Pirated VCDs and DVDs}

The economy is the dominant factor influencing Muslim traders to sell pirated VCDs and DVDs. The merchants sell pirated products with small capital but

${ }^{44}$ Luthfi Assyaukanie, Politik, HAM, dan Isu-Isu Teknologi dalam Fiqh Kontemporer, 1st ed. (Bandung: Pustaka Hidayah, 1998), 30-31.

45 Mustaq Ahmad, Businese Ethics in Islam, ed. Samson Rahman (Jakarta: Pustaka Al-Kautsar, 2000), 142. 
generate large profits. Selling pirated products is an option because selling original products requires significant capital. In addition, the original product is less attractive to consumers because of the high selling price. It results in low profits for traders.

Meanwhile, the profit is more significant from pirated products, apart from the minimal capital. The sale of pirated VCDs and DVDs is an alternative solution to maintain the stability of merchant sales and attract the attention of consumers who have little money. Furthermore, the profits cover their family's daily needs. Authors must be fair in determining the price and benefits of a product or work and create awareness for traders to decide on the practice of trading pirated VCDs and DVDs. Meanwhile, the economic rights granted to the creator sometimes become an obstacle for the public to access a product because the work is considered beyond consumers' ability.

Technological innovation is significant because it helps to promote long-term economic growth. Subsequently, most countries, especially Indonesia, strive to provide an innovation-friendly environment, including tightening the protection of IPR. The study continues about whether a strengthened IPR leads to technological progress and economic growth. The result showed that IPR does promote innovation by protecting the invention appropriation and disclosing knowledge to the public. Nevertheless, there is a creation of an excessive monopoly power, which tends to hinder further innovation. The attention of the copyright holder to the above conditions provides a more appropriate balance and equal access to knowledge, research, and education, for the general public. Meanwhile, creators must remain motivated to produce quality works that are accessible to the public.

Educational factors also influence Muslim traders to sell pirated VCDs and DVDs. The results showed that the traders did not know and understood the MUI fatwa No. 1 of 2003 concerning Copyright. Meanwhile, their education level is not too bad, but not enough to be a benchmark to obey the rules. It is shown from the results of interviews conducted with respondents with various educational backgrounds. Therefore, this study looks at traders' low level of awareness about the rules and prohibitions on selling pirated VCDs and DVDs and their continuation in selling products.

The factor of people's understanding of religious rules also influences Muslim traders to sell pirated VCDs and DVDs. The factor of lack of religious 
understanding causes them to continue to sell pirated products. It led traders to say they continued to sell pirated VCDs and DVDs for profit.

Consequently, the enforcement of the MUI Fatwa No. 1 of 2003 concerning Copyrights for Muslim merchants selling pirated VCDs and DVDs in Manado City did not work effectively. Therefore, several essential elements that are actively involved are needed in supporting the fatwa to be conveyed to merchants and obeyed maximally by the government, ulema, and the general public.

Government involvement in law enforcement is an essential component because they have the authority to make and enforce. The government's role is carried out through legal counseling because many people, especially those living in remote villages and having no educational background, are blind to the law and do not understand why regulations were made. The piracy of VCDs and DVDs causes the legal power of copyright protection in the community not to have been paid much attention to by the public because of the insufficient law enforcement officers enforcing the law against copyright infringers. Therefore, there is a need for the government to enforce copyright laws more optimally.

The role of the government and the ulama is significant for the Muslim community, especially in disseminating the issued fatwas. The reason is that the fatwa issued by the North Sulawesi MUI has not been maximized. According to K.H. Abdul Wahab Abdul Gafur, MUI has not carried out particular socialization to traders but forums for community meetings and several organizations within the MUI office in North Sulawesi and elsewhere.

Evaluation is needed so that Muslim traders know the effectiveness of the fatwa in society. This evaluation is used to measure the actual implementation of the fatwa. Law enforcement officers and public awareness initiate law enforcement to determine the effectiveness of the law. There are two measures to determine the effectiveness of a fatwa, namely, from a juridical and sociological perspective. In addition, there is a tendency for people to view fatwas as binding legal instruments for Muslims. The existence of the law makes the community, including traders, work together and minimize losses due to piracy. Sociologically, fatwas become moral encouragement and provision with high binding power for the perpetrators, especially Muslims. It results in a social movement that is sociologically high enough to protect copyright. Thus, it is known that the public, especially traders and consumers involved in buying and selling VCDs and DVDs at Pasar 45 Manado City, has not used these two standards to obey the law and make fat as a basis for them to live according to Islamic rules. 


\section{Conclusion}

This study shows that although the MUI Fatwa Number 1 of 2003 concerning Copyright has been issued, many traders sell pirated VCDs and DVDs. Five factors are the leading causes: First, public knowledge about the fatwa that prohibits the practice of copyright piracy and their lack of legal awareness. Second, the economic conditions of traders are below the poverty line, so they tend to sell pirated products to meet their daily needs. Third, the religious understanding of the merchants was lacking, causing them to seek all means to make a living. Fourth, the socialization carried out by MUI to traders about the existence of a fatwa and evaluation after the fatwa was issued was not carried out. In conclusion, implementing the MUI Fatwa No. 1 of 2003 concerning Copyright in Market 45 Manado City did not go well and effectively.

This research suggests several things: First, MUI cooperates with the government and law enforcement officials to carry out severe and gradual operations in dealing with copyright infringement in the form of pirated VCDs and DVDs. These operations focus not only on traders and consumers but also prominent agents or manufacturers of pirated products. Sanctions should not only be imposed on hijackers but also buyers. Second, MUI cooperates with the government and law enforcement officials to intensify the MUI Fatwa Number 1 of 2003 concerning Copyright and the Copyright Law. MUI can propose to the government to create job opportunities, provide proper education for citizens, and lower the price of original VCDs and DVDs.[a]

\section{BIBLIOGRAPHY}

Ahmad, Mustaq. Businese Ethics in Islam. Edited by Samson Rahman. Jakarta: Pustaka Al-Kautsar, 2000.

Amin, Ma'ruf. 'Fatwa and The Development of Islamic Financial Industry: A Lesson From Indonesia'. Al-Iqtishad: Journal of Islamic Economics 9, no. 2 (May 2017): 331-50. https://doi.org/10.15408/aiq.v9i2.53 53.

Anggoro, Bayu. 'Pembajakan Hak Cipta di Indonesia Masih Tinggi'. Media Indonesia, September 2019. https://mediaindonesia.com/nusan tara/258462/pembajakan-hak-cipta-di-indonesia-masih-tinggi. 
Aragon, Lorraine V. 'The Problems of Owning Culture: Global Intellectual Property Law and "traditional" Community Arts in Indonesia'. Asian Ethnicity 13, no. 4 (September 2012): 399-417. https://doi.org/10. 1080/14631369.2012.710077.

Arikunto, Suharsimi. Prosedur Penelitian: Suatu Pendekatan Praktik. Jakarta: Rineka Cipta, 2013.

Arli, Denni, and Fandy Tjiptono. 'Consumer Digital Piracy Behaviour among Youths: Insights from Indonesia'. Asia Pacific Journal of Marketing and Logistics 28, no. 5 (November 2016): 898-922. https://doi.org/10.1108/APJML-11-2015-0163.

Assyaukanie, Luthfi. Politik, HAM, dan Isu-Isu Teknologi dalam Fiqh Kontemporer. 1st ed. Bandung: Pustaka Hidayah, 1998.

Badan Pusat Statistik. 'Persentase Penduduk Miskin Maret 2020 Naik Menjadi 9,78 Persen', July 2020. https://www.bps.go.id/press release/2020/07/15/1744/persentase-penduduk-miskin-maret2020-naik-menjadi-9-78-persen.html.

. 'Persentase Penduduk Miskin September 2020 Naik Menjadi 10,19 Persen', February 2021. https://www.bps.go.id/press release/2021/02/15/1851/persentase-penduduk-miskinseptember-2020-naik-menjadi-10-19-persen.html.

Badan Pusat Statistik Republik Indonesia. Potret Sensus Penduduk 2020 Menuju Satu Data Kependudukan Indonesia. Edited by Direktorat Statistik Kependudukan dan Ketenagakerjaan. Jakarta: BPS RI, 2021.

Baene, Christianity Winner. 'Analysis of the Effect of Industrial Sector Exports, Foreign Investment Industrial Sector and Inflation on Indonesia Gross Domestic Product in 1983-2017'. International Journal Public Budgeting, Accounting and Finance 4, no. 1 (February 2021): 1-10.

Baklanova, Olena, Mariana Petrova, and Viktor Koval. 'Institutional Transmission in Economic Development'. Ikonomicheski Izsledvania 29, no. 1 (2020): 68-91. https://ideas.repec.org/a/bas/econst/y20 20i1p68-91.html.

Brander, James A, Victor Cui, and Ilan Vertinsky. 'China and Intellectual Property Rights: A Challenge to the Rule of Law'. Journal of International Business Studies 48, no. 7 (September 2017): 908-21. https://doi.org/10.1057/s41267-017-0087-7.

Brieger, Steven A., Siri A. Terjesen, Diana M. Hechavarría, and Christian Welzel. 'Prosociality in Business: A Human Empowerment 
Framework'. Journal of Business Ethics 159, no. 2 (5 November 2019): 361-80. https://doi.org/10.1007/S10551-018-4045-5.

Bungin, Burhan. Analisa Data Penelitian Kualitatif. Jakarta: PT. Raja Grafindo Persada, 2003.

Cohle, Zachary. 'Global Innovative R\&D Offshoring with Heterogeneous Labor: The Role of IPR-Protection on Technology Transfer and the Brain Drain Effect'. Southern Economic Journal 86, no. 2 (October 2019): 691-725. https://doi.org/10.1002/soej.12397.

Eisend, Martin. 'Morality Effects and Consumer Responses to Counterfeit and Pirated Products: A Meta-Analysis'. Journal of Business Ethics 154, no. 2 (January 2019): 301-23. https://doi.org/10.1007/s10 551-016-3406-1.

Feather, John. 'Copyright and the Creation of Literary Property'. In $A$ Companion to the History of the Book, edited by Simon Eliot and Jonathan Rose, 743-57. John Wiley \& Sons, Ltd, 2019. https:// doi.org/10.1002/9781119018193.CH49.

Gunatilleke, Gehan. 'Justifying Limitations on the Freedom of Expression'. Human Rights Review 22, no. 1 (1 November 2020): 91-108. https:// doi.org/10.1007/S12142-020-00608-8.

Hasyim, Syafiq. 'Fatwas and Democracy: Majelis Ulama Indonesia (MUI, Indonesian Ulema Council) and Rising Conservatism in Indonesian Islam'. TRaNS: Trans-Regional and -National Studies of Southeast Asia 8, no. 1 (May 2020): 21-35. https://doi.org/10.1017/trn.2019.13.

Hurt, Robert M., and Robert M. Schuchman. 'The Economic Rationale of Copyright'. The American Economic Review 56, no. 1/2 (1966): 42132. https://www.jstor.org/stable/1821305.

Hutauruk, Marulam. Peraturan Hak Cipta Nasional. 1st ed. Jakarta: Erlangga, 1982.

Indonesian Presidential Regulation Number 151 of 2014 concerning Funding Assistance for the Activities of the Indonesian Ulema Council, Pub. L. No. 151 of 2014 (n.d.). http://www.bphn.go.id/ data/documents/14pr151.pdf.

Jamaa, La. 'Fatwas of the Indonesian Council of Ulama and Its Contributions to the Development of Contemporary Islamic Law in Indonesia'. IJIMS: Indonesian Journal of Islam and Muslim Societies 8, no. 1 (2018): 29-56. https://doi.org/10.18326/ijims.v8i1.29-56. 
Jayani, Dwi Hadya. 'Jumlah Penduduk Indonesia 269 Juta Jiwa, Terbesar Keempat di Dunia', 2019. https://databoks.katadata.co.id/data publish/2019/04/29/jumlah-penduduk-indonesia-269-juta-jiwaterbesar-keempat-dunia.

Loukil, Kamilia. 'Intellectual Property Rights, Human Capital and Innovation in Emerging and Developing Countries'. Journal of Social Economics Research 7, no. 1 (2020): 35-41. https://doi.org/10. 18488/journal.35.2020.71.35.41.

Meirison, Meirison, and Zerly Nazar. 'Intellectual Property Rights and Monopoly in the Perspective of Islamic Jurisprudence'. Al-Ahkam 31, no. 1 (29 April 2021): 49-68. https://doi.org/10.21580/AHKAM. 2021.31.1.6656.

Mohsin, Asad, Noriah Ramli, and Bader Abdulaziz Alkhulayfi. 'Halal Tourism: Emerging Opportunities'. Tourism Management Perspectives. Elsevier, July 2016. https://doi.org/10.1016/j.tmp. 2015.12.010.

Nurani, Nina, and Hafied Noor Bagja. 'The Effectiveness of Act Number 19 Year 2002 Jo. Act Number 28 Year 2014 Concerning with Copyright as a Protection of Craft Creative Industry to Increase the Acceleration of Creative Economic Growth of Indonesia'. Global Business and Management Research: An International Journal 11, no. 1 (2019): 249-61.

Nurhayani, Neng Yani, and Sarip Muslim. 'Analysis of the Concept of Independence and Professionalism of Indonesian Ulema Council towards Halal Guarantee Certification on Processed Food Industry in West Java'. International Journal of Nusantara Islam 7, no. 1 (March 2019): 49-61. https://doi.org/10.15575/ijni.v7i1.4370.

Nurmusyahidah, Nurmusyahidah, Arfin Hamid, and Andi Tenri Famauri. 'Problematic Financing Fine in Indonesian Ulema Council Perspective'. International Journal of Multicultural and Multireligious Understanding 6, no. 5 (October 2019): 241. https://doi.org/10. 18415/ijmmu.v6i5.1075.

Olivia, Denindah. 'Intellectual Property Regimes to Protect Computer Software: Indonesia and the United States'. Legal Brief 10, no. 1 (November 2020): 8-16. http://legal.isha.or.id/index.php/legal/ article/view/28.

Olubiyi, Ifeoluwa A, Aishatu E Adaji, and Ayokunle F Adetula. 'Increasing the Commercial Value of Image Rights in Nigeria: Legal Possibilities'. 
Journal of Intellectual Property Law \& Practice 15, no. 3 (March 2020): 193-97. https://doi.org/10.1093/jiplp/jpz177.

Prakoso, Jaffry Prabu. 'Pengangguran 2021 Diproyeksi Naik 2 Kali Lipat, Kemiskinan Bisa Double Digit', January 2021. https://ekonomi. bisnis.com/read/20210107/9/1339880/pengangguran-2021-di proyeksi-naik-2-kali-lipat-kemiskinan-bisa-double-digit\#: :text= Pengangguran 2021 Diproyeksi Naik 2 Kali Lipat\%252C Kemis kinan Bisa Double Digit,-Ekonom Senior Institute\&text=Sekitar 2\% 252.

Satori, Djam'an, and Aan Komariah. Metodologi Penelitian Kualitatif. Bandung: Alfabeta, 2011.

Sugiono. Metode Penelitian Pendidikan: Pendekatan Kuantitatif, Kualitatif, Dan R \& D. Bandung: Alfabeta, 2008.

Suharko, Suharko, Siti Daulah Khoiriati, I Made Krisnajaya, and Dedi Dinarto. 'Institutional Conformance of Halal Certifi Cation Organisation in Halal Tourism Industry: The Cases of Indonesia and Thailand'. Tourism: An International Interdisciplinary Journal 66, no. 3 (September 2018): 334-48.

Tan, Winsherly, Elza Syarief, and Rina Shahriyani Shahrullah. 'Combatting Pirated VCDs/DVDs in Batam City, Indonesia: "Facts and Expectations"'. East European Business Law 24, no. 1 (2016): 1-10.

Tuasikal, Rio. 'Rugi 20 Triliun, Pemerintah Perangi Produk Bajakan', September 2019. https://www.voaindonesia.com/a/rugi-20triliun-pemerintah-perangi-produk-bajakan/5077678.html.

Wekke, Ismail Suardi, and Sabil Mokodenseho. 'Religious Teaching and Learning in Minority Muslim of Manado Indonesia'. In 2nd International Conference on Education, Science, and Technology (ICEST 2017), edited by Gufran Darma Dirawan, 187-89. Atlantis Press, 2017. https://doi.org/10.2991/icest-17.2017.62.

Woo, Seokkyun, Pilseong Jang, and Yeonbae Kim. 'Effects of Intellectual Property Rights and Patented Knowledge in Innovation and Industry Value Added: A Multinational Empirical Analysis of Different Industries'. Technovation 43-44 (1 September 2015): 4963. https://doi.org/10.1016/J.TECHNOVATION.2015.03.003. 
